\title{
Child-Resistant Closure
}

National Cancer Institute

\section{Source}

National Cancer Institute. Child-Resistant Closure. NCI Thesaurus. Code C149371.

A closure which is difficult for young children to open but which is not difficult for adults to open properly. 